[Annesley, B. (1993). Performance-Related Pay for Teachers: A Policy Prognosis. New Zealand Annual Review of Education, 2, 135-150]

\section{Performance-Related Pay for Teachers: A Policy Prognosis}

\section{BARBARA ANNESLEY}

$\mathrm{T}$

his article explores the concept of performance-related pay for teachers. Performance-related pay (PRP) can take a number of forms, but is essentially a system of remuneration based fully or partially on the assessment and measurement of an employee's productivity, performance, or skills.

In 1992 a number of references to the introduction of PRP were made by New Zealand Government Ministers and the Education Forum $^{1}$ indicating that performance-related pay for teachers may be on the Government's industrial relations agenda.

This article reviews the recent reforms of educational administration and education sector industrial relations and argues that the introduction of performance-related pay for teachers is ideologically consistent with these reforms, particularly the devolution of staff management to school level and the introduction of the bulk funding of teachers salaries. While performance-related pay may appear to be a perfectly sound concept, overseas experience indicates that there are problems in its application to the teaching profession. These problems are elaborated on in the discussion that follows.

The article concludes that performance-related pay for teachers is unlikely to be introduced without the full implementation of the bulk funding of teachers' salaries and further devolution of staff management responsibilities to boards of trustees.

Teacher Accountability, Educational Reform and Devolved Industrial Relations: Setting the Scene for Performance-Related Pay

The linking of teachers' pay to their performance is closely related to concerns about teacher accountability. In New Zealand, a number of the

\section{Barbara Annesley}

policy documents and reports of the last six years have addressed such concerns.

The first of these was the Report of the Education and Science Select Committee Inquiry into the Quality of Teaching (The Scott Report, 1986). The inquiry was established in response to the Government's perception that "there is considerable disquiet about current methods of accountability in teaching" (The Scott Report, 1986, p. 7).

Though PRP was not directly discussed in the Scott Report, the Committee recommended the introduction of a "lead teacher" scheme (ibid, p. 45), noting "that teachers must feel valued and rewarded for the excellence of their teaching". Details of how the lead teacher scheme would work were scant, and in any case, few of the recommendations contained in the Scott Report were acted on.

Dissatisfaction with existing teacher accountability and remuneration mechanisms was also evident in the 1987 Treasury brief on education issues to the incoming Government. The Treasury stated that,

lack of flexibility (in the present centralised pay fixing system) means that good teachers in shortage subjects tend to be forced out of the classroom to obtain higher pay scales whilst poor or lazy teachers are cross-subsidised by their better or harder-working colleagues (1987, p. 150)

Similar views were held by another influenfial Government control department - the State Services Commission (SSC). The SSC Coordinating Committee, in a 1987 letter responding to the Post Primary Teachers' Association's (PPTA) initial pay claim, proposed greater managerial responsibility for school principals, including the assigning of staff salaries, "taking into account all relevant factors including subject and performance" (cited in Walsh, 1988, p. 53). Though the SSC's proposals were eventually put to one side, they demonstrated the desire of SSC officials to establish a link between teachers' pay and their performance.

In 1987 the Picot Taskforce to Review Educational Administration was established by the Labour Government. According to Capper and Munro (1990, p. 156), dissatisfaction with existing teacher accountability mechanisms was one of the factors in the Government's decision to set up the Taskforce. 
In their report, the Picot Taskforce introduced the notion of "Teachers of Outstanding Merit". This scheme would provide incentives for teachers to remain in the classroom, rather than seek senior positions (1988, p. 70). In its response to the Picot Report (Lange, 1988), the Government endorsed the notion of teachers of outstanding merit, but extended it to encompass the "lead teachers" scheme proposed in the Scott Report (Lange, 1988, p. 10). However, the reforms which eventuated did not follow through this recommendation, which appeared to be ignored in the implementation process.

Despite this omission, the Tomorrow's Schools reforms did introduce a number of changes in education sector industrial relations. While previously, the Director General of Education had been the employing authority for all education sector staff, the Tomorrow's Schools reforms devolved responsibility for appointments, appraisal, staff development and discipline, and salary matters to the level of individual school Boards of Trustees (Lange, 1988, p. 5).

The Tomorrow's Schools reforms introduced the notion of bulk funding for schools. Grants to schools were to have two parts: the operations grant, and the teacher salaries grant. Since it was first proposed, bulk funding of teacher salaries has been a highly contested policy, and has yet to be fully implemented. Currently the majority of schools are bulk funded only for their operations grant, with a small number of schools being bulk funded for teacher salaries on a trial basis in $1992 .^{2}$

The passing of the State Sector Act 1988 accompanied the reform of education administration, introducing a new model of state sector industrial relations, similar to that implemented in the private sector through the Labour Relations Act 1987 (Garlick, 1991, p. 39)

The State Sector Act was amended in 1989, enacting the devolution of the role of employer to individual Boards of Trustees, and providing for the establishment of criteria for the assessment of teacher performance (Rae, 1991, p. 6).

The election of a National Government in 1990 heralded further changes to the industrial relations system. The passing of the Employment Contracts Act, with effect from May 1991, was accompanied by a further amendment to the State Sector Act allowing the State Services Commission to delegate its negotiating powers to Boards of Trustees or a representative body, such as the School Trustees' Association (Rae, 1991, p. 8).
To date, however, the SSC has maintained its role as employer representative body in the negotiation of employment contracts for teachers. Similarly, the Ministry of Education still influences the total salary costs for every school through its role in determining the staffing level of each school and in many instances, its staffing profile.

This retention of central control over teacher salaries reflects the failure of the Government to fully implement the bulk funding of teacher salaries. For as Rae points out, without bulk funding of teacher salaries in place,

... devolution of bargaining to school level would be without appropriate fiscal accountabilities ... on the board as a negotiator. (1991, p. 11)

The analytical framework underpinning the ind ustrial relations changes outlined above is based on a number of theories, ${ }^{3}$ two of which are particularly relevant to this analysis.

Agency theory regards all individuals as self-interested and argues for constraints which ensure that agents pursue the interests of their principals, through the introduction of contracts and measures of acceptable performance (Rae, 1991, p. 12).

Managerialist theory, "stresses the need for organisations to set objectives and develop incentives to ensure that managers better achieve the organisation's goals." (ibid, p. 13)

The notion of performance-related pay builds on these theories and their underlying ideological assumptions. It is also rooted in contracts theory which, "examines the best ways of rewarding workers engaged in different activities in order to maximise benefits and mjnimise costs accruing to the employer." (Munro, 1989, pp. 30-31)

Within the analytical framework generated by these theories, education sector staff are viewed as self-interested, lacking accountability, and with no incentives to ensure quality educational outputs.

Given this view, combined with the Government's concern to contain education sector spending, and the fact that teacher salaries account for seventy-five percent of Government's spending on primary and secondary school education (Gordon, 1992, p. 33), it is not surprising that in 1992, the Government turned its attention to the concept of PRP for teachers. 


\section{The Prospect of Performance-related Pay for Teachers}

In a speech to education sector employers in March 1992, the Minister of Education, Dr Lockwood Smith, remarked that existing teacher collective employment contracts "guarantee teachers built-in pay rises totally unrelated to performance improvements" (Smith, 1992a, p. 5). He claimed that such contracts were fiscally irresponsible, doing nothing to enhance teachers' performance or productivity. The Minister followed by stating his support for PRP for teachers:

I have no doubt that teachers, as professionals, should be paid on performance criteria determined by the local community (and) should be able to be dismissed if not meeting performance requirements. (Smith, 1992a, p. 7)

In June 1992, Dr Smith defended the merit pay and career ladder models of performance pay in a newspaper feature article (Smith, 1992). He argued that many of the recent educational reforms were only symbolic at the level of the school, with teachers and administrators seeking to protect themselves from significant change. The Minister argued that fear of change lay at the heart of teacher union objections to PRP schemes (Smith, 1992).

Dr Smith's calls for PRP for teachers followed similar comments by the Education Forum, in their March 1992 report "Better Teachers for Better Learning" (Education Forum, 1992). This report suggested alternative employment arrangements more conducive to teacher innovation and motivation. The Education Forum proposed a new industrial relations system for teachers, based on individual employment contracts, differential pay according to subject and location, rewards for superior performance, and the assessment of teacher performance prior to the renewal of employment contracts.

Further Government support for the concept of PRP, though not specifically for teachers, can be found in a September 1992 speech to the Employers' Federation by the Minister of State Services and Labour, Bill Birch. Mr Birch commented that it was time to move into the "second phase" of the Employment Contracts Act. Mr Birch included a move "away from pay structures that are related solely to service to those that are skill based" (Birch, 1992, p. 5) in his recommendations for this second phase.

Notably, 1992 also saw a revival of interest in PRP by British and American governments. In the lead-up to the United States presidential elections, both President George Bush and his opponent, Bill Clinton, embraced the idea of PRP for teachers (Business Week, 1992, p. 38).

PRP for teachers is currently being given serious attention by the British Government. Floated initially in 1984 (refer Hartley and Broadfoot, 1988), the notion of PRP resurfaced in 1992 in a report by the School Teachers' Review Body. Under the scheme they proposed, teachers would receive enhanced pay on the basis of whole-school improvements, using indicators such as the extent of vandalism and graffiti, contact with parents, exam results, truancy and the destination of school leavers (Times Educational Supplement, 1 May, 1992).

The Review Body's proposal was rejected by the British Education Secretary, however, who supports the introduction of a scheme where individual teachers are rewarded according to their individual classroom performance and their measured contribution to the education of their pupils (Times Educational Supplement, 31 July, 1992).

\section{Analysis of Performance-Related Pay: Experience From Overseas}

The United States is the home of performance-related pay for teachers. The first "payment by results" schemes were introduced there in the late nineteenth century, and the notion of linking performance to pay has endured, with varying degrees of popularity, up to the present day. Performance pay schemes adopted in other countries have tended to be based on those developed in the United States.

In 1988, 34 American states were either implementing or developing PRP systems (Frase and Poston, 1990, p. 95). It should be noted, however, that the number of American teachers remunerated on the basis of performance is minimal. In 1986, over 99 per cent of public school teachers in the United States were employed under uniform salary scales, and received salaries determined solely on the basis of their educational credentials and experience (Murnane and Cohen, 1986, p. 2).

Four models of PRP predominate in the United States, though particular permutations of these are numerous. The four dominant models are:

Merit Pay: this scheme provides financial remuneration to individual teachers in the form of bonuses (Firestone, 1991; Braithwaite, 1989), usually awarded annually on a one-off basis. 
Career Ladder: this system establishes a career structure for teachers, allowing teachers to progress through staged titles and responsibilities, based on assessment of performance. Such a system incorporates opportunities for professional development, financial rewards and additional duties (Darling-Hammond and Berry, 1988).

Master Teacher: under this scheme individual teachers are rewarded for superior performance. This reward is incorporated into the teacher's base salary and is provided on an on-going basis. Often this model requires teachers to carry out additional tasks (ibid).

Mentor Teacher: under this scheme individual teachers are recognised as experts and as such are financially rewarded for mentoring and supervising colleagues (ibid).

Those who advocate schemes such as those listed above, provide a number of rationales for their position (see Darling-Hammond \& Berry, 1988; Frase \& Poston, 1990). Generally, the objectives of performancebased systems of remuneration are to:

- address public concerns about teacher accountability; enhance the status of teachers;

- motivate teachers to teach better and undertake tasks that they might not otherwise do;

- enhance teacher recruitment and retention; reward superior teachers;

- $\quad$ remedy the inequities of single salary schedules.

Those who oppose performance-based pay for teachers argue that such schemes lead to:

- a narrowing of the curriculum, with a focus on those aspects which are assessed;

- perverse incentives for teachers to spend more time with students whose performance they can have most effect on, and less with the very, and not so able;

- less attention being given to extracurricular duties, such as counselling and sports, which may not be assessed; reduced teacher morale and collegiality between teaching staff;
In addition, opponents claim that such schemes are expensive, and that defining and measuring what constitutes "effective teaching" is problematic.

Given the contradictory claims for PRP, is there, as the Minister of Education has suggested (1992), "a wealth of evidence" for the introduction of such a remuneration system for New Zealand teachers?

Overseas experience of such schemes to date does not reveal the wealth of evidence that the Minister claims. Rather it identifies four key problem areas associated with PRP schemes.

1. The Effects of Performance-Related Pay on Teacher Motivation and Productivity

A central assumption of PRP is that teachers are motivated to improve their performance by the prospect of financial reward (Braithwaite, 1989, p. 5).

This assumption has been challenged by a number of studies (McLaughlin and Marsh 1978; Darling-Hammond 1985, for example) which have found that, providing their base pay is adequate, teachers are motivated more by psychological and intrinsic factors than financial rewards. This is not to suggest that teachers will ignore PRP schemes if they are introduced. Rather, it implies that there may be other more effective ways of improving teacher effectiveness.

PRP provides no incentive or motivation to work harder to those teachers who fail to obtain a reward (McNamara 1992; Bushardt \& Fowler 1987; Murnane and Cohen 1986). Rather, these teachers may become resentful and work at lower levels of performance, particularly if they are not provided with information, support and training to assist them to improve their performance. In addition, the adoption of PRP schemes may encourage teachers to conceal their weaknesses, rather than seek help in correcting them.

\section{Defining and Measuring Effective Teaching}

The assessment of performance is the pivotal element in any PRP scheme. It is notable that an inability to devise fair systems of performance evaluation has been one of the key reasons that most merit pay schemes in the United States have been abandoned within five years of their introduction (Darling-Hammond \& Berry, 1988, p. 54). 
There are two main approaches to assessing teacher performance. One is to assess outputs, or student attainment. Some merit pay schemes have attempted to do this by relating rewards to student test scores. Bushardt and Fowler (1987) refer to this as the "value-added approach". Investigations into such practices have found that,

If rewards are linked to achievement test results, teachers soon subvert the intentions of the total curriculum to concentrate on those

areas that are part of the assessment process. (Braithwaite, 1989, p. 6)

Such systems may provide incentives for teachers to spend less on those whose test scores are unlikely to respond to increased attention (Murnane and Cohen 1986; McNamara 1992). It should be noted however, that no causal link has been established between PRP schemes and improved student results (McNamara, 1992).

Determining the contribution that an individual teacher makes to pupil performance is problematic in itself. A whole range of school and non-school variables, such as school climate, previous instructional treatment, home environment, social class and ability, affect student achievement.

A second approach to assessing teacher performance is to measure inputs, or those factors associated with effective teaching. However, in order to do this we must be able to define what constitutes "effective" teaching.

This is not as easy as it sounds, for teaching lacks clear specifications as to the characteristics of effectiveness. McDonald (1985) recalls research findings indicating 132 different skills and behaviours manifested by teachers regarded as effective. Clearly it would be very difficult to design an evaluation system which measured all these factors.

Hartley and Broadfoot (1988) state that "there is little or no evidence to support the idea that teacher effectiveness can be systematically evaluated". They cite two reasons for this: the inability to isolate and measure the teacher's part in the learning process, and the inability to eliminate subjectivity in the assessment process. Further, as Byrne (1983, p. 1) points out, the effectiveness of a teacher may vary from topic to topic, and from one type of pupil to another.

Bushardt and Fowler haveidentified a further problem with teacher evaluation for pay purposes:
By using the performance review for merit pay decisions, the performance review process is diverted from its primary purpose of professional development to that of its impact on salary ... (1987, p. 30)

Teaching is constrained by resource limitations, social, economic and political pressures, institutional frameworks, moral and ethical considerations and policy decisions (Archer, 1983, p. 55). Thus, schooling and teaching - and the criteria employed in judging them - cannot be evaluated without consideration of the wider context in which they operate.

\section{Funding Considerations}

Another major factor in the eventual abandonment of most PRP schemes in the United States has been cost escalation. In Arizona, for example, the cost of a merit pay scheme initiated in 1985 has risen from $\$ 100,000$ to $\$ 21.1$ million per annum (Business Week, 1992, p. 38)

As the PPTA has so baldly phrased it, "the trouble with performance pay is that if you get the performance you have to produce the pay" (1992, p. 4)

There are two standard ways of avoiding cost escalations. One is to set a limit on the amount of money available for performance pay. The other is to set a quota on the number of people in receipt of rewards (National Union of Teachers, 1992, p. 8).

Setting a limit on the amount of money available for allocation can have the effect of making the reward so small that it is unlikely to have any effect on teacher motivation or performance. On the other hand, imposing a quota on the number of awards available may cause teachers to become more competitive and less likely to share ideas and practices (Braithwaite, 1989, p. 7).

As well as establishment costs, there are hidden costs associated with the administration and evaluation requirements of PRP schemes. In one American school district, principals estimated that they spent from 15 to 50 per cent of their time on the evaluation process (Suffolk Education Department, 1986, p. 18).

PRP originated in the private sector, where schemes have been both successful and financially sustainable. However, this is due to the direct relationship that exists between improved employee performance and increased financial returns to the business. The same cannot be said of teaching. 
4. EEO Considerations

Overseas experience suggests that women whose performance and seniority is measured as equal to that of their male colleagues are less likely to receive performance-related pay increases or awards (National Union of Teachers, 1992, p. 9)

There is no reason to assume that such a sex-bias would not occur if performance pay was introduced in New Zealand. Evidence of this can be found in the Teacher Career and Promotion Study (TEACAPS). This study looked, inter alia, at the operation of the primary assessment or "grading" scheme. The 1982 TEACAPS report and 1987 update "The Position of Women in Education", showed that women primary teachers consistently receive lower assessments than their male colleagues.

\section{Research Which Supports Performance-Related Pay for Teachers}

There appears to be very little in the literature which supports PRP for teachers. The research findings that do exist are qualified with references to a set of ideal conditions or features which must apply often not as preconditions for success, but in order that the scheme does not have a negative effect.

Braithwaite (1989, p. 4) for example, outlines four crucial conditions which must prevail if PRP schemes are to motivate teachers to improve their performance: an adequate base pay, incentives representing an appreciable amount of money; a belief amongst employees that their performance does actually influence their pay; and a valuing by employees of income as a reward.

Even if these conditions can be achieved, Braithwaite argues that addressing the aspects of the conditions of teaching that milita te against effective teaching is a more appropriate strategy for improving performance than the introduction of performance-related pay.

Murnane and Cohen (1986) looked at six enduring and successful merit pay schemes in the United States. Each was located in a school district which had a higher than average salary scale, good working conditions and was regarded as a desirable district in which to teach (Murnane and Cohen, 1986, p. 11). The six schemes also shared a number of other common characteristics to which their longevity was attributed: extra pay for extra work; making everyone feel special by rewarding almost all teachers; giving the scheme a low profile; and legitimating the scheme by involving teachers in its design and operation (ibid, 1986).

As Murnane and Cohen note, many of these characteristics in fact undermine the intentions of PRP. Paying teachers for extra work is not the same as paying teachers for better work. Rewarding virtually all teachers undermines the intention of using differential pay as an incentive to improve performance. And giving a scheme a low profile may mean that teachers are unable to gain information about the skills and characteristics which are associated with rewards, and thus strive to acquire them.

\section{Performance-Related Pay in the New Zealand Context}

Given the recent attention to PRP by our Ministers of Education and Labour, it is useful to explore what a New Zealand performance-pay system might look like.

The Minister of Education has hinted that school trustees would be involved in the teacher assessment process, and that "ownership" of the scheme would be located at the level of the school (Smith, 1992). He also proposed that teacher assessment should be based on" multiple criteria, multiple judging and multiple data sources" (1992). These are all desirable characteristics for a PRP scheme. They are also likely to be costly and time-consuming to implement and maintain. One can only speculate whether school trustees and administrators will be resourced and trained to carry out fair and comprehensive evaluations of teacher performance. And school "ownership" of a PRP scheme implies that individual or site-based employment contracts for teachers would be necessary.

In his 1992 article, Dr Smith stated that student learning outcomes, such as exam results, should be one measure of teacher performance, though he acknowledged the "technical and philosophical difficulties in trying to measure the influence teachers have on their pupils" (Smith, 1992). He maintains, however, that there is enough evidence to support such an approach being adopted. Despite an extensive literature review, no such evidence has been unearthed by this writer.

Union opposition to any proposal for the introduction of PRP for teachers is likely to be just as vigorous as that directed at the Government's bulk funding policy. The NZEI and PPTA regard teacher salary bulk funding, individual contracts and differential pay as an 
equation for the de-collectivisation of the teaching profession, and subsequent weakening of their bargaining power.

In his 1992 newspaper article the Minister of Education confirmed the integral relationship between the bulk funding of teacher salaries and PRP. Certainly, without bulk funding in place, schools would not bear any of the financial responsibility for their decisions regarding teacher salaries.

The Government's arguments for PRP are presented in terms of improved teacher performance and accountability. However, as Harris (1992, p. 10), has pointed out, these goals are incompatible with the Government's objective of fiscal constraint. What is more likely is that Government, through the implementation of teacher salaries bulk funding and the further devolution of the employer responsibilities to school boards of trustees, is seeking to contain educational spending and absolve itself of responsibility for school staffing matters. Performance-related pay for teachers is but another mechanism for achieving this objective.

\section{Conclusions}

Several recent statements by Ministers of the Crown and the Education Forum provide evidence to suggest the possible introduction of performance pay for teachers in New Zealand. Such a move has already been enabled by the recent reforms of educational administration and state sector industrial relations. It also appears to be compatible with the Government's desire to introduce bulk funding of teacher salaries.

However, as an analysis of the literature on overseas schemes suggests, there is little evidence to support the introduction of PRP as a means of improving teacher performance, and thus the learning outcomes of students.

Three central problems have yet to be resolved in the century or more during which performance pay has waxed and waned in the United States. They are: the requirement for substantial and ongoing funding, the inability to define and measure teacher effectiveness, and the lack of evidence establishing a link between PRP and improved teacher or student performance.

A number of negative consequences of PRP schemes have also been identified. These include the detrimental effect of evaluation for pay purposes on the staff development aspect of appraisal, a narrowing of the curriculum, the undermining of EEO policies and a negative effect on staff relations.

There is little in the literature which supports the introduction of performance-pay for teachers. While the arguments for PRP are presented in terms of increased teacher accountability and improved performance, in reality this objective cannot be achieved without substantial financial investment - an unlikely prospect in times of government expenditure constraints.

Any proposals to introduce performance-related pay in New Zealand in the presenteconomic and industrial relations climate should be resisted by those with a concern for educational standards. It is fiscal, and not educational objectives that are likely to propel us towards its introduction.

\section{Notes}

1. The Education Forum is a lobby group established by the Business Round table to comment on education issues and make recommendations to Government.

2. For an in-depth review and analysis of the bulk funding of teacher salaries, refer Gordon (1992).

3. According to Boston (1991, cited in Gordon, 1992) these include public choice theory, agency theory, transaction cost analysis and the "new public management".

\section{References}

Archer, Eric "Do We Know Anything About Effective Teaching?" Delta 32, 1983.

Birch, Bill Speech to the Employers' Federation's New Zealand Business and Industry Advisory Council's Labour Market Group, 1 September 1992.

Braithwaite, R. J. "Merit Pay as a Policy for Improving Quality in Education: A Review of Current Practices" in New Education Vol.11, No.1, 1989.

Bushardt, Stephen and Fowler, Aubrey "Improving Teaching Effectiveness: Merit Pay vs. Organisational Culture" in Capstone Journal of Education Vol. 7, No. 2, Winter, 1987.

Business Week "Merit Pay for Teachers May Not Have Much Merit" in Business Week, March 1992.

Byrne, Colin "The Conceptualisation of Effectiveness and the Assessment of Teachers" CORE (Collected Original Resources in Education) Vol. 7, No. 1, 1983. 
Capper, Phillip Trends in Performance Pay (unpublished PPTA internal memo), 1992.

Capper, Phillip, and Munro, Rae "Professionals or Workers? Changing Teachers' Conditions of Service". In Middleton S., Codd J., and Jones A. (eds) New Zealand Education Policy Today: Critical Perspectives. Allen and Unwin, Wellington, 1990.

Darling-Hammond, Linda and Berry, Barnett The Evolution of Teacher Policy Rand Corporation and the Centre for Policy Research in Education, March, 1988.

Education and Science Select Committee Report on the Inquiry into the Quality of Teaching (The Scott Report). Wellington: Government Printer, 1986.

Education Forum Better Teachers For Better Learning: Teacher Employment Conditions - Current and Prospective. March, 1992.

Firestone, William "Merit Pay and Job Enlargement as Reforms: Incentives, Implementation, and Teacher Response" in Educational Evaluation and Policy Analysis Vol. 13, No. 3, Fall, 1991.

Frase, Larry and Poston, William Jnr "Teacher Incentive Programs: Diversity and Effectiveness without State Funding" in Clearing House Vol. 64, No. 2, November/December, 1990.

Garlick, Mary Teacher Appraisal Within the New Zealand Reform of Education Administration. Unpublished MPP Thesis, Victoria University of Wellington, 1991.

Gordon, Liz "The Bulk Funding of Teachers' Salaries: A Case Study in Education Policy" In Manson, H. (ed) New Zealand Annual Review of Education. Wellington: Victoria University, 1992

Harris, Peter Resourcing - How Are We Going to Pay for Education? (Background Notes for a Panel Discussion at the Profitable Education Conference), Wellington, 30-31 July 1992.

Hartley, Larry and Broadfoot, Patricia "Assessing Teacher Performance" in Journal of Education Policy, Vol. 3, No. 1, January-March, 1988.

Lange, David Tomorrow's Schools: The Reform of Education Administration in New Zealand. Wellington: Government Printer, 1988.

McDonald, Ron "Assessing Teacher Effectiveness" The New Zealand Principal Vol. 11, No. 3, 1985

McNamara, David "Three Times Unlucky". Times Education Supplement June 5, 1992.

Munro, Rae The Munro Report: Research into the Provisions of Tomorrow's Schools. February, 1989.

Murnane, Richard and Cohen, David"Merit Pay and the Evaluation Problem: Why Most Merit Pay Plans Fail and Few Survive" in Harvard Educational Review Vol. 56, No. 1, February, 1986.
National Union of Teachers Pay Teachers Properly: The Case Against Performance Related Pay. United Kingdom, 1992.

New Zealand Educational Institute Better Teachers for Better Learning? - Or Someone Hasn't Done Their Homework: An Analysis of the Education Forum's March 1992 Report. NZEI, Wellington, March, 1992.

PPTA (Post Primary Teachers' Association) Salaries Bulk Funding: A Review of the PPTA Case Against, for Those Wishing to Understand the Arguments in Depth. Wellington, August, 1992.

Rae, Kenneth Industrial Relations For New Zealand Teachers. (A paper prepared for the First New Zealand Conference on Research in Educational Administration), Auckland, 7-9 July 1991

Smith, Hon Lockwood "Teachers Must Step on to the Career Ladder" in The Dominion, 23 June, 1992.

Smith, Hon Lockwood Speech to Education Sector Employers, Tumbull House, Wellington, 12 March 1992.

Suffolk Education Department "Those Having Torches ... The Graham Report: A Study into Teacher Appraisal by the Suffolk Education Department". Journal of Evaluation in Education Issue 9-10, April, 1986.

Taskforce to Review Education Administration Administering for Excellence: Effective Administration in Education. (The Picot Report) Wellington: Government Printer, 1988.

The Treasury Government Management: Brief to the Incoming Government, Volume II: Education Issues. Wellington: Government Printer, 1987.

Times Education Supplement "Patten Snubs his Advisers on Merit Pay", July 31, 1992.

Times Education Supplement "Preparing to Put on a Performance", May 1,1992. Walsh, Pat "Accountability and the Industrial Relations Climate" in Wylie, Cathy (ed) Proceedings of the First Research Into Education Policy Conference. New Zealand Council for Educational Research, 17-19 August 1988.

Wells, Pamela "Policy Developments in the US. A" In Lokan, J and McKenzie, P. (eds) Teacher Appraisal: Issues and Approaches. Australian Council for Educational Research, Melbourne, 1989.

\section{The author}

Barbara Annesley is a Master of Education student at Victoria University. She has worked for the Ministry of Education in the area of tertiary policy implementation for a number of years. Currently she is working full-time on her thesis on tertiary education policy. 